Federal Reserve Bank of New York

Staff Reports

\title{
Determinants of Mortgage Default and Consumer Credit Use: The Effects of Foreclosure Laws and Foreclosure Delays
}

\author{
Sewin Chan \\ Andrew Haughwout \\ Andrew Hayashi \\ Wilbert van der Klaauw
}

Staff Report No. 732

June 2015

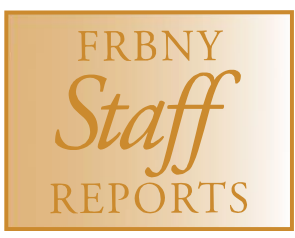

This paper presents preliminary findings and is being distributed to economists and other interested readers solely to stimulate discussion and elicit comments. The views expressed in this paper are those of the authors and do not necessarily reflect the position of the Federal Reserve Bank of New York or the Federal Reserve System. Any errors or omissions are the responsibility of the authors. 


\title{
Determinants of Mortgage Default and Consumer Credit Use: The Effects of Foreclosure Laws and Foreclosure Delays
}

Sewin Chan, Andrew Haughwout, Andrew Hayashi, and Wilbert van der Klaauw

Federal Reserve Bank of New York Staff Reports, no. 732

June 2015

JEL classification: D12, D14, G1, K10

\begin{abstract}
The mortgage default decision is part of a complex household credit management problem. We examine how factors affecting mortgage default spill over to other credit markets. As home equity turns negative, homeowners default on mortgages and HELOCs at higher rates, whereas they prioritize repaying credit cards and auto loans. Larger unused credit card limits intensify the preservation of credit cards over housing debt. Although mortgage non-recourse statutes increase default on all types of housing debt, they reduce credit card defaults. Foreclosure delays increase default rates for both housing and non-housing debts. Our analysis highlights the interconnectedness of debt repayment decisions.
\end{abstract}

Key words: mortgage default, state foreclosure laws, consumer finance

Chan: New York University (e-mail: sewin.chan@nyu.edu). Haughwout: Federal Reserve Bank of New York (e-mail: andrew.haughwout@ny.frb.org). Hayashi: University of Virginia (e-mail: ath9f@virginia.edu). Van der Klaauw: Federal Reserve Bank of New York (e-mail: wilbert.vanderklaauw@ny.frb.org). The authors thank Brandi Coates and Sara Shahanaghi for exceptional research assistance and the Russell Sage Foundation for their financial support. They are grateful to Vicki Been, Quinn Curtis, Robert DeYoung, Ingrid Ellen, Rich Hynes, the staff at New York University's Furman Center for Real Estate and Urban Policy, and participants at the annual meetings of the Association for Public Policy Analysis and Management, the Eastern Economic Association, and the American Real Estate and Urban Economics Association for their helpful comments and suggestions. The views expressed in this paper are those of the authors and do not necessarily reflect the position of the Federal Reserve Bank of New York or the Federal Reserve System. 


\section{Introduction}

The massive home equity losses arising from the housing market collapse that began in 2006 and the subsequent wave of foreclosures has been well documented. However, little is known about how homeowners managed their use of credit during this time. Faced with declining home values and a challenging labor market, and amid considerable uncertainty about how long the recession would drag on, how did households apportion their limited financial resources to repay loans and preserve access to credit? This paper exploits unique panel data derived from credit reports to provide the first comprehensive evidence at the individual level for how homeowners manage credit during periods of financial stress.

Historically, homeowners have placed home mortgages at the top of their debt payment hierarchy. Our empirical approach uses data from 2002 to 2011 to explore how factors affecting mortgage default may affect that payment hierarchy and spill over onto other credit default decisions. We focus on four variables to explain defaults on credit cards, auto loans, home equity lines of credit (HELOCs) and second mortgages or home equity loans (HELOANs): (1) the homeowner's combined home equity position, (2) the amount of unused credit limit on credit cards and HELOCs, (3) whether the primary mortgage provides the lender with recourse to the borrower's assets, and (4) the expected time between default and foreclosure completion in the homeowner's county. We also control for individual credit score and we capture the local labor market and macroeconomic environment using CBSA-quarter fixed effects. ${ }^{1}$

We find that homeowners managed their use of housing and non-housing debt in a way

\footnotetext{
${ }^{1}$ A core based statistical area (CBSA) is the collective term for metropolitan and micropolitan statistical areas. According to the Census, it consists of "counties or equivalent entities associated with at least one core (urbanized area or urban cluster) of at least 10,000 population, plus adjacent counties having a high degree of social and economic integration with the core as measured through commuting ties with the counties associated with the core.”
} 
that is broadly consistent with a rational, forward-looking, approach to credit default and to preserving access to credit. Those with higher combined loan-to-value ratios (LTVs) are more likely to default on HELOCs and HELOANs as well as their primary mortgage. At the same time, as home equity declines, homeowners have lower probabilities of credit card and auto loan default. These results suggest strategic decisions by homeowners to preserve access to credit card borrowing and the use of vehicles as their housing wealth declines. Additional support for this interpretation comes from our finding of lower rates of credit card default and higher rates of housing debt default among those with larger unused credit card limits.

We confirm an established empirical finding that having a non-recourse primary mortgage, i.e., a mortgage for which lenders may not look to other assets of the borrower in the event of default on an under-collateralized loan, increases the likelihood of primary mortgage default, especially for underwater homeowners. We further establish a link between the recourse status of the primary mortgage and defaults on other housing debt: HELOC and HELOAN default is more likely if a homeowner's primary mortgage is non-recourse, particularly if home equity is negative.

Importantly, we find that this mortgage-specific legal institution spills over to nonhousing debt: credit card default rates are $18 \%$ lower among underwater homeowners if the primary mortgage is non-recourse. A forward-looking homeowner who expects to default on her primary mortgage will also expect to lose access to other borrowing secured by her home, increasing the incentive to preserve access to credit card borrowing. Moreover, a homeowner with a non-recourse mortgage has more wealth than an equally underwater homeowner with a recourse mortgage because her other assets are freed from the claims of the mortgage lender. For a given income trajectory, greater wealth increases the demand for credit, leading to stronger 
incentives to preserve credit card borrowing among non-recourse mortgage borrowers.

Consistent with other literature examining the effect of judicial foreclosures, we find that expected delays in the foreclosure process are associated with increased rates of primary mortgage default among underwater homeowners. Defaulting homeowners can continue living in their homes free of rent payments until the foreclosure process is fully completed and they are evicted from the property. The longer this period of free rent, the greater the incentive to default on the mortgage.

The effect of foreclosure delay on non-housing debts could in theory go in either direction. As we explain further in the body of the paper, the effect could be in the same direction as the anti-deficiency statutes due to a similar wealth effect and motive for credit preservation. However, there is an opposing effect from the transitory free rent that could lessen the demand for credit as future expenses will be higher once foreclosure eviction occurs. We find that this transitory effect dominates and that foreclosure delays increase credit card defaults; credit card default rates are 57\% higher among underwater homeowners if the expected delay in the homeowners' county is at least 9 months, compared to when the delay is up to three months.

Our analysis highlights the interconnectedness of household default decisions on different credit accounts, revealing that variables conventionally thought to drive primary mortgage default have large effects on other default decisions as well. In particular, the effects of antideficiency statutes and foreclosure delay, which have previously only been explored in the context of mortgage default, spill over onto non-mortgage markets. 


\section{Connections to the Literature}

This paper connects two lines of research that have flourished in the wake of the recent housing market boom and bust. The first explores how households juggle payment priorities and rebalance their household balance sheets in response to changes in home prices. The second examines the effects of institutional factors and legal rules on the mortgage default decision. The richness of our data allow us to make contributions to both sets of questions independently, but also to bridge the two by examining how factors applicable to mortgage default affect other consumer finance behavior.

\subsection{The Effects of Home Equity on Household Borrowing}

Housing represents a large share of the typical household balance sheet and so it is not surprising that the performance of housing markets and the borrowing behavior of households are intricately linked; as such, there is a large literature exploring the use of home equity. ${ }^{2}$ Our study builds most directly on two papers that, like ours, match credit records to data on mortgage originations to track home equity and payment priorities during the housing boom and bust. Andersson et al. (2013) study a sample of subprime borrowers from 2001 to 2009 and document a shift in payment priorities over time towards repaying credit cards rather than mortgages, a shift that they attribute largely to the increased desirability of strategic default post-2008 as well as increased mortgage servicing costs and a changing composition of borrowers and mortgage products. Our work extends Andersson et al. by looking at the spillover effects of mortgage default on loans other than credit cards, and finds corroborating evidence for strategic default

\footnotetext{
${ }^{2}$ Recent studies include Mian and Sufi (2011), Mian et al. (2013), Ramcharan and Crowe (2013), Krainer (2012), Bhutta (2012), Demyanyk and Koepke (2012), Abdallah and Lastrapes (2012) and Gist et al. (2012).
} 
considerations by focusing on the effects of being underwater or having lower foreclosure costs. Jagtiani and Lang (2011) explore patterns of default between first and second lien mortgages. They find that a large share of borrowers who were delinquent on their first mortgage kept their second-lien mortgage current during the recent recession. Evidence of prioritizing credit card debt also been reported by Transunion (2012), and Cohen-Cole and Morse (2010) who, like us, argue that preserving access to credit has been an important motivation for prioritizing credit cards over mortgages.

Another contribution of this paper is our use of zip code level home price indices to dynamically estimate each homeowner’s equity position. By contrast, Cohen-Cole and Morse (2010) use state-level housing price indices and Andersson et al. (2013) measure housing price changes at the MSA level. As noted by Sinai (2012), there is considerable heterogeneity in the timing, length and amplitude of the housing boom and bust across metropolitan areas. That said, our more geographically specific measure of home equity also includes more endogeneity than would arise when using aggregate housing price changes as home equity depends on loan size as well as housing price changes. For example, homeowners with larger loans (and thus higher LTVs) may on average be more creditworthy than other homeowners because their earnings history supported more borrowing, or they may be less creditworthy because they had accumulated less of a down payment. We consider these concerns in greater depth when discussing our results.

\subsection{The Effects of Foreclosure Law and Processing on Mortgage Default}

The literature generally views mortgage default as the exercise of a put option by the mortgagor. Whether this option is in-the-money depends on a number of factors, including the 
applicable foreclosure laws and the foreclosure processing rate of local courts. The literature has focused on two such factors: (1) whether a lender has recourse to a mortgagor's other assets if the value of the foreclosed property is less than the amount owed on the mortgage and (2) the amount of time from default (90 days of delinquency) to foreclosure eviction. The former is limited by the existence of anti-deficiency statutes in some states, and the latter depends on factors including whether the foreclosure process is subject to oversight by a court (judicial foreclosure) and the rate at which foreclosures can be processed. ${ }^{3}$ This second factor is especially important during periods with high rates of foreclosure, when judicial or administrative resources might be binding constraints on foreclosure processing.

Although early models of default largely ignored the effects of these legal factors, Jones (1993) provides a framework that incorporates both the value of rent-free housing services received by homeowners in the period from default until foreclosure completion, as well as the expected recovery that the mortgagee can obtain from the mortgagor's other assets. Ambrose et al. (1997) incorporate foreclosure delay and deficiency judgments into an option pricing model to explore the effects that they have on the costs and benefits of default and the value of the implicit put option in a mortgage contract. The benefits of default include eliminating a negative equity position and living rent-free until eviction. The costs include a potential deficiency judgment and the costs of relocation. Because a homeowner does not lose her property until the foreclosure is completed, it is the expected value of the property at that time that matters, so foreclosure delay has two benefits: a longer period of rent-free living and the reduction in the present value of any deficiency judgment. Ambrose et al. predict that increases in foreclosure

\footnotetext{
${ }^{3}$ Demiroglu et al. (2013) report data from Citibank indicating that the average time from delinquency to liquidation in judicial review states is 20 months compared to 15.7 months in non-judicial review states. Gerardi et al. (2013) also find that judicial foreclosure and right-to-cure laws extend the foreclosure timeline.
} 
delay lead to increasing rates of default, with larger effects for homeowners with higher LTVs.

They also predict that increasing the likelihood of deficiency judgments reduces the likelihood of default. These theoretical predictions find some support in the data.

The balance of the empirical evidence suggests that the availability of lender recourse and foreclosure delay do affect the likelihood of mortgage default. Jones (1993) finds that the unavailability of recourse doubled or tripled the incidence of default during a period of housing price declines in Canada. Demiroglu et al. (2014) find that judicial review and the unavailability of deficiency judgments are associated with higher rates of default for borrowers with negative home equity. Ghent and Kudlyak (2011) also find that recourse reduces mortgage default for underwater homeowners, particularly for properties with appraised values in the $\$ 500,000$ to $\$ 750,000$ range. Like these two studies, our identification of the effect of non-recourse status uses both within-state differences between purchase mortgages, which often are covered by antideficiency statutes, and refinanced mortgages, which typically are not, as well as between-state variation in legal rules. Unlike these studies, the richness of our data allows us to exploit only that cross-state variation that exists within CBSAs in a given quarter.

On the other hand, Li and Oswald (2013) examine the effect of abolishing deficiency judgments in Nevada in 2009 and do not find an effect on mortgage default or foreclosures. They suggest that evidence of anti-deficiency statutes' effects on default may be due to selection bias, with lenders lending to riskier borrowers when they can obtain deficiency judgments. ${ }^{4}$ Desai et al. (2013) also find that judicial foreclosure increases defaults and foreclosure rates but they do

\footnotetext{
${ }^{4}$ A related literature examines the effect of anti-deficiency statutes and time until foreclosure on mortgage originations. In theory, the effects are ambiguous since laws that are more favorable to lenders should increase supply but decrease demand for mortgages. Curtis (2013) finds that lender-friendly foreclosure is associated with an increase in subprime originations, but has less effect on the origination of prime loans. Pence (2006) finds that judicial foreclosure requirements result in loans that are 3\% to 7\% smaller. Li and Oswald (2013) find that lenders tightened lending standards after deficiency judgments were terminated in Nevada in 2009.
} 
not find effects of anti-deficiency statutes and redemption rights. Although successful recovery of deficiencies from recourse loans is a rare occurrence (Haughwout et al. 2013), Ghent and Kudlyak (2011) observe that the threat of such a judgment may drive borrowers to convey deeds in lieu of foreclosure or to conduct short sales to avoid personal liability, generating real effects on homeowner behavior precisely because of the incentive effects. In this paper we provide corroborating evidence that foreclosure delay and the threat of a deficiency judgment affect mortgage default decisions.

But the primary contribution of our paper is to capture the connections between mortgage default decisions and other consumer finance choices, and bridge the literature on the institutional determinants of mortgage default with the literature on the effect of home equity on household borrowing, We believe that ours is the first study to examine the effect of legal rules on payment priorities and on default decisions for non-mortgage credit accounts. Because mortgage default has effects on the rest of a household's balance sheet, non-recourse statutes and foreclosure delay should be expected to have effects beyond the mortgage market, and indeed we find that they do. By incorporating these elements, our analysis paints a rich picture of consumer credit default decisions in response to financial stress against the backdrop of legal rules and practices.

\section{Framing and Methodology}

The decision to default on a credit account is embedded in a complex dynamic decision problem that involves all credit accounts. Factors affecting this decision include current and expected future demand for credit, the time path and riskiness of income, and the costs and 
benefits of prioritizing each credit account over the others. In this section we discuss the basic economics of these factors in order to frame our empirical analysis.

\subsection{Factors Driving Housing Debt Default}

A homeowner's demand for credit will depend on her permanent income, the expected trajectory and riskiness of that income over the lifecycle, and her preference for inter-temporal consumption smoothing. In a steady state without uncertainty, a homeowner should generally repay all debts on time. However, a variety of financial and institutional variables are likely to increase the probability of mortgage default in an environment with unanticipated housing price and income variability. For example, larger mortgage payments are more likely to result in default when a homeowner is faced with a negative income shock. Negative home equity creates an incentive for mortgage default, if by defaulting the homeowner is relieved of the excess liability. This incentive will be strongest in jurisdictions where home mortgages are nonrecourse, that is, where a borrower is not personally liable for the excess of the mortgage balance over the value of the property securing it. The time that lapses from mortgage default until foreclosure completion also creates an incentive to default as defaulting homeowners can live in their homes, rent-free, until they are evicted. The length of time from default until foreclosure depends on the formal procedures that must be followed to complete a foreclosure, as well as on resource constraints affecting the ability of courts or banks to process those foreclosures.

Defaulting on a primary mortgage has future consequences that a rational borrower will take into account. A borrower who defaults will lose any future appreciation in the value of the home if she does not cure her default, and so expectations of future housing price increases should reduce the likelihood of default. A defaulting borrower will also lose access to the use of 
her home as collateral, and so a borrower with limited credit alternatives has greater incentive to remain current on her primary mortgage. On the other hand, a borrower who intends to default on her primary mortgage has an incentive to prioritize remaining current on her credit cards over a HELOC, because although both credit cards and HELOCs are substitute revolving lines of credit, the HELOC will dry up after the home has been foreclosed upon.

Default on other forms of housing debt, such as HELOCs and HELOANs, should generally exhibit the same relationship with financial and institutional variables as primary mortgages since these defaults will also precipitate foreclosure proceedings. A homeowner has less incentive to remain current on any debt secured by her home the more underwater the property is, with the effect being greater in non-recourse jurisdictions. Future increases in home prices should reduce the likelihood of HELOC and HELOAN default, and larger debts should be associated with the higher probabilities of default. The more valuable the homeowner's other sources of credit, the more likely she should be to default on her housing debt.

\subsection{Factors Driving Non-Housing Debt Defaults}

Decisions to default on housing debt are interconnected with decisions to default on other credit accounts, and the same factors that drive housing debt default decisions should also affect defaults on non-housing debt. A homeowner who defaults on her mortgage will reduce her access to credit in the mortgage and home equity markets. With access to certain lines of credit curtailed, there will be an increased incentive to preserve access to credit cards and other nonhousing debt. The extent to which other lenders penalize mortgage defaulters in their access to 
credit is unknown. ${ }^{5}$ Moreover, for a given mortgage default induced decline in credit score, it is unclear how other lenders will respond, although it seems likely that they will be more lenient with existing clients than with potential new clients of similar score. If they react by shutting off all access to credit, then it would be futile for a mortgage defaulter to try to preserve access to these alternate credit sources. In this case, we would expect defaults to be positively correlated and factors affecting mortgage default to affect default on these other loans in similar ways. But, if other lenders are slow to respond, perhaps because they weight repayment history on their own accounts more heavily, then there will be an incentive for mortgage defaulters to try to preserve access to other accounts by making payments promptly. In this case, factors affecting mortgage default will have the opposite effect on defaults on other loans. Ultimately, how defaulting households respond will depend on what they believe the other non-mortgage lenders will do, and the direction of effects is an open empirical question.

If households believe that existing credit cards can be preserved, we would expect higher LTVs to reduce the probability of credit card default as consumers substitute away from housing debt to other forms of consumer credit. The unused amount of credit in a credit card account increases the insurance value of the credit card against future income shocks, and thus we would expect the extent of an unused credit limit to reduce the likelihood of credit card default.

If the credit preservation motive is important, the effect of mortgage default factors on non-mortgage default behavior will also be affected by a homeowner’s demand for credit: greater credit demand will, all else equal, lead these factors to have opposite effects on nonmortgage default, while lower credit demand will lead these factors to have similar effects on

\footnotetext{
${ }^{5}$ A mortgage default will certainly reduce the borrower's credit score but by how much will also depend on other factors and the exact formula is a trade secret. The only definitive information from Fair Isaac is that the score will be negatively affected for 7 years.
} 
non-mortgage default. A homeowner who is underwater on a non-recourse mortgage has more wealth than an otherwise identical homeowner who is equally underwater on a recourse mortgage. All else equal, this greater wealth will be associated with greater demand for credit because increases in wealth increase planned consumption in all future periods. Given an unchanged path for labor income, greater wealth will be associated with less saving or more borrowing, depending on the homeowner's borrowing position. Thus, on average, non-recourse statutes increase the demand for credit via a wealth effect and we would expect borrowers with negative home equity to have lower credit card default rates if their primary mortgage is nonrecourse than if it is recourse. This wealth effect and non-housing credit preservation motive is reinforced by the fact that mortgage default will foreclose the availability of HELOCs and HELOANs to finance consumption.

Likewise, the rent-free housing consumption derived from foreclosure delay is equivalent to a transitory increase in income, that could generate a wealth and credit preservation effect similar to that for the non-recourse statute. However, this increase in transitory income from free rent will also temporarily reduce the demand for credit. To the extent this dampens any credit preservation motive, a long foreclosure delay would serve to increase credit card defaults, just as it increases mortgage default. Thus, the direction of effect on foreclosure delay is theoretically ambiguous and depends on whether this transitory income effect dominates the wealth and credit preservation effect.

As with housing debt, the relative size of a credit account balance will likely affect the probability of defaulting on that account, if only because the cost of keeping that account current is apt to be greater. The amount of outstanding consumer debt as a share of housing debt, or the required payment on consumer debt relative to mortgage payments, captures the overall non- 
mortgage debt burden relative to mortgage debt. For a given individual, the larger the nonhousing debt burden, the greater the potential value of non-housing default, other things equal.

\subsection{Empirical Strategy}

To explore the effects of housing-related financial and institutional variables on mortgage default and other consumer credit outcomes, we estimate the following reduced-form econometric model.

$$
\begin{gathered}
y_{i z c m s t}=\gamma \text { nonrecourse }_{i s}+\text { DELAY }_{\text {ct }-1} \Gamma+\operatorname{LTV}_{i t} \beta+\delta h p i_{z t+1}+ \\
\lambda_{1} \text { cclimit }_{i t}+\lambda_{2} \text { heloclimit }_{i t}+\text { BALANCES }_{i t} \Theta+X_{i t} \Psi+ \\
C B S A \times T I M E_{m t} \Omega+\epsilon_{i t}
\end{gathered}
$$

$y_{i z c m s t}$ is a default indicator for a type of credit account (primary mortgage, HELOC, HELOAN, credit card or auto loan) for individual $i$ in zip code $z$, in county $c$, in CBSA $m$, in state $s$ at time $t$. The first two explanatory variables capture our two legal variables of interest. nonrecourse $_{\text {is }}$ is a dummy variable equal to 1 if $i$ 's primary mortgage is non-recourse in the state in which the property is located. As noted above, non-recourse status varies by state as well as by whether the mortgage secures a purchase or refinanced loan. $D E L A Y_{c t-1}$ is a vector of dummy variables indicating whether the expected time from default to foreclosure completion in the county at time $t-1$ is from 0 to 3 months, 3 to 6 months, 6 to 9 months, or more than 9 months (measurement details are below). ${ }^{6}$ The remaining variables in the equation capture financial and economic factors. $L T V_{i t}$ is a vector of indicators for the combined LTV of the

\footnotetext{
${ }^{6}$ Lenders may not have been able to initiate the foreclosure process at default (defined as 90 days past due) because of resource constraints and so our measure includes delays in both the commencement of foreclosure proceedings and the time from commencement until completion. Because we cannot observe the date at which the foreclosure process began, we cannot disentangle the two; however, it is the expected rent free period that is relevant for borrowers' decisions, and the date at which foreclosure proceedings actually begin are of secondary importance.
} 
property. The denominator of LTV is calculated by increasing the purchase price of the home by the same percentage as the change in HPI for the property's zip code over the relevant period. ${ }^{7}$ Using perfect foresight as a proxy for individual expectations of housing price appreciation, we include a variable for the percentage change in the individual's zip code level HPI over the six months following $t .{ }^{8}$ We also include unused credit card and HELOC limits, and either outstanding account balances relative to mortgage debt, or the minimum required payments relative to mortgage payments. $X_{i t}$ is a collection of control variables for individual $i$ at time $t$, including the individual's age, credit score in the previous quarter, and the origination year of the primary mortgage.

We include CBSA-quarter fixed effects to control for local, time-varying, economic and institutional shocks that may be correlated with our variables of interest. In particular, we view these fixed effects as a high-quality control for local labor market effects, which may be correlated with housing price shocks reflected in our LTV variables. ${ }^{9}$ Our inclusion of these fixed effects implies that we are identifying the effect of non-recourse statutes using withinCBSA, cross-state, variation, and within-state variation by purchase versus refinance mortgage borrowers. It is often difficult to identify the effect of state-level policy variables because other factors that vary by state can be difficult to control for. We believe our identification strategy provides a measure of the effect of non-recourse statutes that controls well for other economic variables, making our estimates an improvement on those that rely primarily on state-level variation.

\footnotetext{
${ }^{7}$ Classical measurement error introduced by use of zip code level HPI would lead to attenuation bias in our estimates of the effect of LTV.

${ }^{8}$ While unlikely to be true, we chose perfect foresight as a proxy because it is available by zip code and relatively transparent. The literature on house price expectations offers no standard method for how they should be empirically estimated.

${ }^{9}$ We obtain virtually identical results to those shown below when we include only loans within MSAs and estimate the models with MSA-quarter fixed effects.
} 


\section{Data}

We use data from the Federal Reserve Bank of New York Consumer Credit Panel / Equifax (CCP) matched with loan-level data from CoreLogic's LoanPerformance database. The CCP is a quarterly panel starting in 1999 that tracks the individual Equifax credit records of a five percent nationally-representative sample of individuals with credit reports and Social Security numbers. The data include a wide range of credit attributes for each individual, including the number of credit cards, auto loans, mortgages and HELOC accounts, the balances of those accounts, and whether those accounts are delinquent or in default. The data also include information on the individuals' ages, credit scores, census block, and whether the individuals have entered into bankruptcy or foreclosure. Lee and van der Klaauw (2010) provide a detailed description of the CCP.

The CCP data include information about mortgage loans, but not the value of the properties securing the loans. To identify the amount of home equity, a sample of individuals were matched with data on individual loans from LoanPerformance, a mortgage database that covers over 90 percent of all non-prime securitized mortgages in the U.S. The match allows us to calculate the amount of home equity held by a sample of the CCP borrowers at the origination of their mortgages. ${ }^{10}$

We restrict our matched sample to those individuals who took out a first lien home mortgage between 2002 and 2006 and we follow them in our data until either the first quarter of 2011, the mortgage terminates, or the mortgage has been in default for one year, whichever is

\footnotetext{
${ }^{10}$ The match was performed by CoreLogic using private identifying variables that are not part of the resulting merged dataset.
} 
earliest. We also exclude individuals who were missing records in the CCP for two or more consecutive quarters and the small number of individuals who defaulted on their mortgage and then became current on the same mortgage within a year. ${ }^{11}$ In order to focus our analysis on owner-occupants rather than investors, we dropped individuals who had more than one primary mortgage outstanding for more than two consecutive quarters at any time during the sample time frame. We also restrict our sample to individuals that had credit card debt at some point during the sample period, and who did not have a student loan or an unidentifiable "other debt” as information on these accounts were known to be problematic. When examining auto loans, HELOCs and HELOANs, we limit the sample to only those individuals who had such loans during our sample period.

We estimate each individual’s home equity at dates subsequent to origination using zip code level HPIs from Zillow. Approximately 7.5 percent of individuals in our sample lived in zip codes that had no HPI and had to be dropped from our analysis. Our final sample includes 396,924 individual-quarter observations from 49,481 mortgages. The sample is representative of individuals with credit cards who took out a first lien non-prime securitized mortgage between 2002 and 2006 to purchase a primary residence in a zip code with an HPI. ${ }^{12}$

Data on which states have anti-deficiency (i.e., non-recourse) statutes was taken from Ghent and Kudlyak (2011). Some states’ anti-deficiency statutes apply only to purchase mortgages. Our data include both purchase mortgages and refinances, and we code each loan’s recourse status accordingly.

Whereas Ghent and Kudlyak use the availability of judicial foreclosures as a proxy for

\footnotetext{
${ }^{11}$ Including this latter group does not qualitatively change our results, regardless of whether we code them as remaining in default or not.

12 The number of mortgages originated in each year is 3,502 in 2002, 6,213 in 2003, 11,240 in 2004, 15,785 in 2005, and 12,741 in 2006.
} 
foreclosure delay, we generate direct estimates of the expected time from default until eviction. We use the $25^{\text {th }}$ percentile of the foreclosure delay distribution for all foreclosures that were completed one quarter before the observation quarter in the homeowner's county. ${ }^{13}$ We chose the $25^{\text {th }}$ percentile instead of the median to account for possible homeowner risk aversion over the amount of time they can reasonably expect to live rent free; however, our results below are qualitatively similar if we use the median. We believe that our direct estimates of the time from default until foreclosure are preferable to the state-level proxy variables used in other studies because our measures capture variation over time and within the state. During the Great Recession, the length of foreclosure delays increased significantly in some areas as a flood of foreclosures overwhelmed the ability of courts and banks to process them in a timely fashion. The effect of institutional constraints on foreclosure delay is omitted from studies that look only at whether states have judicial foreclosure or not.

Table 1 reports summary statistics for our covariates, separately for individual-quarter observations in which the homeowner was at least 90 days past due on her primary mortgage and observations in which the homeowner was not. Those in default on their primary mortgage are much more likely to be in default on their other credit accounts: 54 percentage points more likely for HELOCS, 50 for HELOANs, 35 for credit cards, and 13 for auto loans. Such homeowners are also likely to have exhausted a larger share of their credit card and HELOC limits and to live in zip codes with the fastest-falling housing prices. Although homeowners in mortgage default are as likely to have a non-recourse mortgage as homeowners not in default, they are more likely to have higher LTVs, lower credit scores, and live in counties with longer foreclosure delays.

\footnotetext{
${ }^{13}$ We use a random $20 \%$ sample of the entire LoanPerformance database (not just mortgages in our matched sample) to calculate the time from mortgage default until REO for each loan that entered REO during our sample period. We then took the 25th percentile of this empirical distribution for all properties that entered REO in each county-quarter.
} 
The age distribution of our defaulting homeowners is roughly the same as for non-defaulting homeowners.

\section{Results}

We estimate equation (1) as a linear probability model for a series of dependent variables that includes default on housing debt (the primary mortgage, HELOCs and HELOANs), and default on other consumer credit (credit cards and auto loans). We rely on the ability to control for an assortment of individual characteristics as well as CBSA-quarter fixed effects to identify the effects of our financial and legal variables of interest. Tables 2 and 3 report the results. For each dependent variable, the first column reports the coefficient estimates for the entire sample, while the second through fourth columns report estimates for the observations in which the homeowner has a combined LTV less than $90 \%$, between $90 \%$ and $110 \%$, and above $110 \%$.

\subsection{Housing Debt Default}

Table 2 shows large and statistically significant effects of combined LTV on the probability of homeowner default on primary mortgages, HELOCs and HELOANs. Relative to homeowners with at least $20 \%$ equity in their home (the reference group), homeowners that are underwater by $0-10 \%$ (combined LTV of 100-110\%) are 3.1 percentage points more likely to default on their primary mortgage. The same homeowners are 1.7 and 1.1 percentage points more likely to default on their HELOC and HELOAN respectively, if they have them. The effects are much stronger as the homeowner slips further underwater. Those who are at least $20 \%$ underwater are 11.9 percentage points more likely to default on their primary mortgage, 4.1 
percentage points more likely to default on a HELOC, and 5.3 percentage points more likely to default on a HELOAN.

The probability of defaulting on any housing debt is generally increasing in the size of the primary mortgage balance and also in the size of the debt itself (normalized by the size of the primary mortgage balance) in the case of HELOCs and HELOANs. For all three kinds of housing debt, the effect of the debt amount on default is largest for the most underwater homeowners. The positive correlation between debt size and default could reflect homeowners under financial strain who have extracted home equity to smooth consumption, or it could simply result from greater debt service burdens.

As expected, future housing price changes have large and statistically significant negative effects on the probability of defaulting on primary and second mortgages, though we find no significant effect for HELOCs. A one percentage point increase in area home price appreciation (or reduction in home price decline) over the subsequent six months is associated with a 15.0 percentage point decrease in the probability of primary mortgage default and a 12.6 percentage point decrease in the probability of defaulting on a second mortgage. The effects are even stronger for homeowners who are at least $10 \%$ underwater on the value of their home. For such homeowners, a one percentage point increase in home price appreciation is associated with 16.6 and 19.2 percentage point declines in the probability of primary and second mortgage default, respectively. We would not expect past changes in housing prices to independently affect the probability of default if our other control variables, including LTV, adequately capture the homeowner's financial position, and indeed, we find no significant effect of past housing price changes when included as an additional control in these models.

We include as explanatory variables lagged unused credit card and HELOC limits to 
account for incentives that homeowners have to remain current on those accounts to preserve access to credit. The results in Table 2 show that unused credit card limits are positively associated with primary mortgage, HELOC and HELOAN defaults, especially for underwater borrowers. This result is consistent with prioritizing credit card debt over housing debt in order to preserve access to a larger credit line, perhaps in anticipation of mortgage default. If, on the other hand, large unused credit card limits were generally indicative of a financially healthy household, we would not expect it to be positively correlated with housing debt default. We also find a very small positive effect of unused HELOC limits on primary and secondary mortgage default, though these are not generally significant when we disaggregate the full sample by LTV.

Turning to our legal and institutional variables, we find that whether a primary mortgage is non-recourse affects not just default on that mortgage, but default for other housing debts, especially for those who have an LTV of at least $110 \%$. For these homeowners, the effect of a loan being non-recourse is to increase the probability of mortgage default by 2.6 percentage points (14\%), of HELOC default by 3.2 percentage points (32\%), and of default on a second mortgage by 2.6 percentage points (32\%). This result is consistent with the predictions of Ambrose et al. (1997) and the findings of Ghent and Kudlyak (2011) and Demiroglu et al. (2014). For homeowners who are at least 10 percent underwater, an expected foreclosure delay of nine months or more increases the probability of primary mortgage default by 7.4 percentage points (40\%), relative to a delay of less than three months. We do not observe statistically significant relationships between foreclosure delay and default on HELOCs and HELOANs.

\subsection{Credit Card and Auto Loan Default}

The interconnectedness of credit default decisions suggests that financial and institutional 
variables that have previously been analyzed only for their effects on primary mortgage default could also affect other consumer credit outcomes. Table 3 displays estimates of equation (1) for credit card and auto loan default. The results show that as an individual's home equity position worsens, she becomes less likely to default on her credit card accounts and auto loans. We interpret this as evidence that homeowners prioritize remaining current on their non-housing debt in anticipation of mortgage default and the loss of credit secured by their home. As a homeowner slips underwater, it becomes optimal to shift payment priorities in a way that preserves access to credit cards and the consumption value of the homeowner's vehicle, rather than to remain current on housing debt.

Although larger primary mortgage loan balances are associated with higher rates of home default, we find the opposite effect on credit card and auto loan default. Higher primary mortgage balances are associated with reduced rates of credit card and auto loan default, which is also consistent with remaining current on credit cards and auto loans in anticipation of mortgage default. To capture the burden of credit cards, we use the lagged minimum credit card payment due (estimated as 3 percent of the credit card balance), relative to the lagged primary mortgage payment, and find that credit card defaults are higher when the required credit card payment relative to the mortgage payment is large. ${ }^{14}$ This result is similar to that for HELOC and HELOAN balances in Table 2. We do not observe robust effects of auto loan balances on auto loan default.

Large unused credit card limits are associated with lower rates of credit card default. We expect individuals to prioritize credit accounts with higher unused limits because they have greater value as insurance against negative income shocks. Higher HELOC limits, on the other

\footnotetext{
${ }^{14}$ We obtain a similar result if we instead use credit card balances relative to the primary mortgage balance.
} 
hand, increase the probability of credit card default for homeowners with at least $10 \%$ home equity; as the value of a HELOC increases, the relative value and incentive to remain current on a consumer line of credit falls.

We note that our analysis assumes that a homeowner's credit risk is adequately controlled for by including credit score and age. It is possible that there is some residual variation in creditworthiness across homeowners that is captured by some of our other explanatory variables. For example, higher LTV at origination, larger credit card and HELOC limits, and higher debt balances may all be correlated with a homeowner having demonstrated to a lender's satisfaction that she is a low credit risk. But although this would explain the negative relationships between these variables and credit card default, this explanation is inconsistent with the positive correlations we identified between these variables and mortgage, HELOC and HELOAN default. Conversely, if these variables tend to be associated with increased credit risk, this would explain our housing debt results but not our credit card results. We have also rerun our models excluding borrowers whose primary mortgages were refinances as they too may be less risky in unobserved ways. This reduces the sample size by about half and removes one source of variation in nonrecourse status, so that only within CBSA, cross-state variation in non-recourse remains. We find that virtually all of our findings are robust to this sample restriction.

Among borrowers who are at least $10 \%$ underwater, having a non-recourse mortgage reduces credit card default by 2.4 percentage points (18\%). When the primary mortgage is nonrecourse, a defaulting homeowner can walk away from the mortgaged property with a balance sheet that is relieved of the excess liability associated with a home that is underwater. Thus, as discussed earlier, the ability to default on an underwater non-recourse mortgage represents greater wealth relative to a similar homeowner with a recourse mortgage, and this greater wealth 
could result in increased demand for credit. In addition, because anti-deficiency statutes increase the attractiveness of mortgage default, which will foreclose the availability of HELOCs and HELOANs to finance consumption, homeowners have more incentive to remain current on their credit cards to preserve access to any credit.

For homeowners who are at least $10 \%$ underwater, there is a positive and statistically significant effect of foreclosure delay on the probability of credit card default. The longer the underwater homeowner is able to live in their home rent-free following default, the more likely she is to default on her credit cards. A delay of over nine months increases the probability of default by 7.7 percentage points (57\%) relative to a delay of only three months or less. This may initially seem surprising because of the opposite effect of non-recourse mortgages, described above, even though both make mortgage default more attractive, increase wealth for underwater borrowers and eliminate future access to HELOCs and HELOANs. As discussed in section 3.2, homeowners experience what is effectively a transitory positive income shock in the period from default to foreclosure in the form of free housing. In other words, the wealth effect from foreclosure delay comes from an upfront reduction in expenditures (the free rent). Thus, during this period, which may be substantial, there is likely much lessened demand for credit, as future expenses will be higher because of rent payments. The empirical result that we find suggests that the transitory income effect dominates the wealth and future credit preservation effects, leading to increased credit card default. There is weak evidence of a similar effect for auto loan defaults.

While we argued earlier that we prefer our time-varying county-specific measures of foreclosure delay over the state-level proxy variables used in other studies, we reran our models using judicial foreclosure indicators. Consistent with our displayed findings, these state level indicators have a significant and positive effect on credit card defaults that is largest in 
magnitude for underwater borrowers.

\section{Conclusions}

Understandably, much research on the housing market collapse that accompanied the Great Recession has focused on the causes and consequences of primary mortgage default. But the decision to default on a primary mortgage is only one part of a complex household maximization problem, reflecting the current and expected future value of the collateral property, the consequences of mortgage default on access to credit in the future, and prioritizing certain credit accounts over others during a period of widespread cash illiquidity and financial stress. The primary contribution of our paper is to connect the financial and legal determinants of mortgage default with other consumer finance decisions. We have described how households juggle payment priorities on their credit accounts in response to the financial and institutional drivers of primary mortgage default, to paint a more complete picture of what policymakers can expect during a housing downturn. Our results make clear that mortgage default arises as a substitute for default on other credit accounts, and penalizing mortgage default, such as by repealing anti-deficiency statutes, could lead to higher rates of default on credit cards and auto loans.

Our work also highlights the benefits of using individual level data to understand how homeowners manage credit, and to disentangle the effects of changes in housing prices and the amount of home equity on household behavior. Within areas with declining home values, there is important heterogeneity in homeowner behavior that cannot be identified using aggregate measures. Controlling for changes in neighborhood housing prices and local economic shocks, 
we show that those with limited or negative home equity behave differently from other homeowners. 


\section{References}

Abdallah, Chadi S., and William D. Lastrapes. (2012). "Home equity lending and retail spending: Evidence from a natural experiment in Texas.” American Economic Journal: Macroeconomics 4: 94-125.

Ambrose, Brent W., Richard J. Buttimer, and Charles A. Capone. (1997). "Pricing Mortgage Default and Foreclosure Delay.” Journal of Money, Credit \& Banking 29.3: 314-325.

Andersson, Fredrik, Souphala Chomsisengphet, Dennis Glennon, and Feng Li. 2013. “The Changing Pecking Order of Consumer Defaults.” Journal of Money, Credit and Banking 45:251-275.

Bhutta, Neil. (2012). "Mortgage debt and household deleveraging: accounting for the decline in mortgage debt using consumer credit record data.” http://ssrn.com/abstract=2027262

Cohen-Cole, Ethan, and Jonathan Morse. (2010). "Your House or Your Credit Card, Which Would You Choose? Personal Delinquency Tradeoffs and Precautionary Liquidity Motives.” Working Paper No.QAU09-05, Federal Reserve Bank of Boston.

Curtis, Quinn. (2013). "State Foreclosure Laws and Mortgage Origination in the Subprime.” Journal of Real Estate Finance and Economics 47(2): 1-26.

Demiroglu, Cem, Evan Dudley, and Christopher M. James. (2014). "State Foreclosure Laws and the Incidence of Mortgage Default.” Journal of Law and Economics 57.1: 225-280.

Demyanyk, Yuliya, and Matthew Koepke. (2012). “Americans Cut Their Debt. Economic Commentary.” http://www.clevelandfed.org/research/commentary/2012/2012-11.cfm.

Desai, Chintal A., Gregory Elliehausen, and Jevgenijs Steinbuks. (2013). "Effects of bankruptcy exemptions and foreclosure laws on mortgage default and foreclosure rates.” Journal of Real Estate Finance and Economics 47.3: 391-415. 
Gerardi, Kristopher, Lauren Lambie-Hanson, and Paul S. Willen. (2013). "Do borrower rights improve borrower outcomes? Evidence from the foreclosure process.” Journal of Urban Economics 73: 1-17.

Ghent, Andra C., and Marianna Kudlyak. (2011). "Recourse and residential mortgage default: evidence from US states.” Review of Financial Studies 24: 3139-3186.

Gist, John R., Carlos Figueiredo, and Satyendra K. Verma. (2012). "Boom and bust: Housing equity withdrawal and consumption decisions and their impacts on household wealth.” Journal of Aging \& Social Policy 24:1-28.

Haughwout, Andrew, Sarah Sutherland, and Joseph Tracy. (2013). “Negative Equity and Housing Investment.” Federal Reserve Bank of New York Staff Reports, no. 636.

Jones, Lawrence D. (1993). “Deficiency judgments and the exercise of the default option in home mortgage loans.” Journal of Law and Economics 36:115.

Krainer, John. (2012). Consumer Debt and the Economic Recovery. FRBSF Economic Letter. http://www.frbsf.org/publications/economics/letter/2012/el2012-25.html.

Jagtiani, Julapa, and William W. Lang. (2011). “Strategic Default on First and Second Lien Mortgages During the Financial Crisis.” Journal of Fixed Income 20(4): 7-23.

Lee, Donghoon, and Wilbert van der Klaauw. (2010). An Introduction to the FRBNY Consumer Credit Panel. FRB New York Staff Report 479. http://www.newyorkfed.org/research/ staff_reports/sr479.html.

Li, Wenli, and Florian Oswald. (2013). Recourse and Mortgage Default: the Case of Nevada. Mian, Atif, Kamalesh Rao and Amir Sufi. (2013). "Household Balance Sheets, Consumption, and the Economic Slump.” Quarterly Journal of Economics 128(4):1687-1726

Mian, Atif, and Amir Sufi. (20110. "House Prices, Home Equity-Based Borrowing, and the U.S. 
Household Leverage Crisis.” American Economic Review 101:2132-2156.

Pence, Karen M. (2006). “Foreclosing on opportunity: State laws and mortgage credit.” Review of Economics and Statistics 88:177-182.

Ramcharan, Rodney, and Christopher Crowe. (2013). “The impact of house prices on consumer credit: evidence from an internet bank.” Journal of Money, Credit and Banking 45: 10851115.

Sinai, Todd M. (2012). “House Price Moments in Boom-Bust Cycles.” NBER Working Papers Series \#18059

Transunion. (2012). "Payment Hierarchy Analysis: A Study of Changes in Consumer Payment Prioritization from 2007 through 2011.” http://www.transunion.com/docs/rev/business/marketperspectives/financialservices/indus tryTrends/Payment_Hierarchy_White_Paper.pdf. 
Table 1. Summary Statistics

\begin{tabular}{|c|c|c|c|}
\hline \multirow{2}{*}{\multicolumn{2}{|c|}{ Percent of sample, unless otherwise noted }} & \multicolumn{2}{|c|}{ Mortgage is in Default } \\
\hline & & Yes & No \\
\hline \multicolumn{2}{|l|}{ HELOC default } & $54.6 \%$ & $0.6 \%$ \\
\hline \multicolumn{2}{|l|}{ HELOAN default } & $50.5 \%$ & $0.7 \%$ \\
\hline \multicolumn{2}{|l|}{ Credit card default } & $45.3 \%$ & $10.1 \%$ \\
\hline \multicolumn{2}{|l|}{ Auto loan default } & $15.7 \%$ & $2.3 \%$ \\
\hline \multicolumn{2}{|l|}{ Median Primary mortgage balance } & $\$ 218,662$ & $\$ 181,000$ \\
\hline \multicolumn{2}{|l|}{ Average HELOC debt / Primary mortgage debt } & 0.039 & 0.043 \\
\hline \multicolumn{2}{|l|}{ Average HELOAN debt / Primary mortgage debt } & 0.034 & 0.029 \\
\hline \multicolumn{2}{|c|}{ Average Minimum credit card payment / Primary mortgage payment } & 0.194 & 0.189 \\
\hline \multicolumn{2}{|c|}{ Average Auto loan debt / Primary mortgage debt } & 0.060 & 0.053 \\
\hline \multicolumn{2}{|l|}{ Average Change in zip code HPI in next 6 months } & $-2.8 \%$ & $-0.8 \%$ \\
\hline \multicolumn{2}{|l|}{ Average Unused \% of credit card limit } & $22.1 \%$ & $54.3 \%$ \\
\hline \multicolumn{2}{|l|}{ Average Unused \% of HELOC limit } & $1.2 \%$ & $6.0 \%$ \\
\hline \multicolumn{2}{|l|}{ Non-recourse primary mortgage } & $21.2 \%$ & $22.4 \%$ \\
\hline \multirow[t]{4}{*}{ Expected months from default to eviction in county*: } & $0-3$ months & $8.6 \%$ & $15.2 \%$ \\
\hline & $3-6$ months & $49.5 \%$ & $52.1 \%$ \\
\hline & 6 - 9 months & $25.4 \%$ & $17.4 \%$ \\
\hline & $9+$ months & $16.1 \%$ & $12.5 \%$ \\
\hline \multirow[t]{6}{*}{ Combined LTV: } & below 80 & $16.0 \%$ & $52.3 \%$ \\
\hline & $80-90$ & $14.4 \%$ & $17.6 \%$ \\
\hline & $90-100$ & $16.6 \%$ & $14.4 \%$ \\
\hline & $100-110$ & $13.9 \%$ & $6.8 \%$ \\
\hline & $110-120$ & $10.4 \%$ & $3.2 \%$ \\
\hline & $>120$ & $28.8 \%$ & $5.7 \%$ \\
\hline \multirow[t]{6}{*}{ Age: } & 25 and under & $1.9 \%$ & $1.5 \%$ \\
\hline & $26-35$ & $21.7 \%$ & $19.8 \%$ \\
\hline & $36-45$ & $33.8 \%$ & $31.0 \%$ \\
\hline & $46-55$ & $24.8 \%$ & $25.3 \%$ \\
\hline & $56-65$ & $12.7 \%$ & $14.4 \%$ \\
\hline & $65+$ & $5.1 \%$ & $8.0 \%$ \\
\hline \multirow[t]{9}{*}{ Credit score: } & Under 530 & $58.3 \%$ & $6.2 \%$ \\
\hline & $530-560$ & $13.1 \%$ & $3.7 \%$ \\
\hline & $560-590$ & $10.5 \%$ & $5.5 \%$ \\
\hline & $590-620$ & $7.4 \%$ & $7.3 \%$ \\
\hline & $620-650$ & $4.5 \%$ & $8.7 \%$ \\
\hline & $650-680$ & $2.6 \%$ & $9.5 \%$ \\
\hline & $680-720$ & $1.9 \%$ & $13.4 \%$ \\
\hline & $720-750$ & $0.8 \%$ & $10.8 \%$ \\
\hline & $>750$ & $1.1 \%$ & $34.9 \%$ \\
\hline \multirow[t]{5}{*}{ Primary mortgage origination year: } & 2002 & $2.6 \%$ & $6.1 \%$ \\
\hline & 2003 & $3.6 \%$ & $14.0 \%$ \\
\hline & 2004 & $9.5 \%$ & $23.0 \%$ \\
\hline & 2005 & $30.9 \%$ & $33.4 \%$ \\
\hline & 2006 & $53.4 \%$ & $23.5 \%$ \\
\hline \multicolumn{2}{|l|}{ Number of individual-quarter observations } & 19,450 & 377,474 \\
\hline
\end{tabular}

Source: FRBNY-CCP/Equifax and LoanPerformance: individuals with credit cards who originated a first-lien non-prime securitized mortgage 2002-06 for a primary residence in a zip code with an HPI, tracked until a year after default or 2011. Italics indicate the reference category in the regressions shown in subsequent tables.

*Does not sum to $100 \%$ due to a small number of missing values. 
Table 2. Housing Debt Default

\begin{tabular}{|c|c|c|c|c|c|c|c|c|c|c|c|c|}
\hline \multirow{2}{*}{$\begin{array}{l}\text { Dependent variable: } \\
\text { Sample: }\end{array}$} & \multicolumn{4}{|c|}{ Mortgage Default } & \multicolumn{4}{|c|}{ HELOC Default } & \multicolumn{4}{|c|}{ HELOAN Default } \\
\hline & All & LTV: $<90$ & LTV: $90-110$ & LTV: >110 & All & LTV: $<90$ & LTV: $90-110$ & LTV: $>110$ & All & LTV: $<90$ & LTV: 90-110 & LTV: $>110$ \\
\hline Combined LTV (lag): & & & & & & & & & & & & \\
\hline $80-90$ & $\begin{array}{l}-0.0006 \\
(-0.75)\end{array}$ & $\begin{array}{l}0.0088 \\
(11.65)^{* * *}\end{array}$ & & & $\begin{array}{l}-0.0025 \\
(-1.78)\end{array}$ & $\begin{array}{l}0.0024 \\
(1.81)\end{array}$ & & & $\begin{array}{l}0.0001 \\
(0.09)\end{array}$ & $\begin{array}{l}0.0043 \\
(6.64)^{* * *}\end{array}$ & & \\
\hline $90-100$ & $\begin{array}{l}0.0106 \\
(11.06)^{* * *}\end{array}$ & & $\begin{array}{l}-0.0145 \\
(-7.48)^{* * *}\end{array}$ & & $\begin{array}{l}0.0057 \\
(2.33)^{*}\end{array}$ & & $\begin{array}{l}-0.0058 \\
(-1.17)\end{array}$ & & $\begin{array}{l}0.0010 \\
(1.22)\end{array}$ & & $\begin{array}{l}-0.0058 \\
(-5.21)^{* * *}\end{array}$ & \\
\hline $100-110$ & $\begin{array}{l}0.0309 \\
(19.29)^{* * *}\end{array}$ & & & & $\begin{array}{l}0.0171 \\
(4.48)^{* * *}\end{array}$ & & & & $\begin{array}{l}0.0113 \\
(9.90)^{* * *}\end{array}$ & & & \\
\hline $110-120$ & $\begin{array}{l}0.0632 \\
(24.25)^{* * *}\end{array}$ & & & $\begin{array}{l}-0.0401 \\
(-11.45)^{* * *}\end{array}$ & $\begin{array}{l}0.0247 \\
(4.74)^{* * *}\end{array}$ & & & $\begin{array}{l}-0.0053 \\
(-0.73)\end{array}$ & $\begin{array}{l}0.0280 \\
(15.58)^{* * *}\end{array}$ & & & $\begin{array}{l}-0.0092 \\
(-3.20)^{* *}\end{array}$ \\
\hline $120+$ & $\begin{array}{l}0.1190 \\
(49.47)^{* * *}\end{array}$ & & & & $\begin{array}{l}0.0412 \\
(9.05)^{* * *}\end{array}$ & & & & $\begin{array}{l}0.0531 \\
(28.81)^{* * *}\end{array}$ & & & \\
\hline In(Primary mortgage balance) (lag) & $\begin{array}{l}0.0298 \\
(47.91)^{* * *}\end{array}$ & $\begin{array}{l}0.0112 \\
(20.00)^{* * *}\end{array}$ & $\begin{array}{l}0.0464 \\
(22.04)^{* * *}\end{array}$ & $\begin{array}{l}0.0865 \\
(22.49)^{* * *}\end{array}$ & $\begin{array}{l}0.0103 \\
(9.34)^{* * *}\end{array}$ & $\begin{array}{l}0.0062 \\
(6.53)^{* * *}\end{array}$ & $\begin{array}{l}0.0193 \\
(3.51)^{* * *}\end{array}$ & $\begin{array}{l}0.0362 \\
(4.77)^{* * *}\end{array}$ & $\begin{array}{l}0.0104 \\
(13.89)^{* * *}\end{array}$ & $\begin{array}{l}0.0016 \\
(2.65)^{* *}\end{array}$ & $\begin{array}{l}0.0180 \\
(12.88)^{* * *}\end{array}$ & $\begin{array}{l}0.0303 \\
(8.73)^{* * *}\end{array}$ \\
\hline Account balance / primary mortgage balance (lag) & & & & & $\begin{array}{l}0.0041 \\
(1.34)\end{array}$ & $\begin{array}{l}0.0120 \\
(5.79)^{* * *}\end{array}$ & $\begin{array}{l}0.0616 \\
(4.72)^{* * *}\end{array}$ & $\begin{array}{l}0.0657 \\
(3.71)^{* * *}\end{array}$ & $\begin{array}{l}0.0048 \\
(1.32)\end{array}$ & $\begin{array}{l}0.0007 \\
(1.13)\end{array}$ & $\begin{array}{l}0.1020 \\
(23.71)^{* * *}\end{array}$ & $\begin{array}{l}0.1790 \\
(7.04)^{* * *}\end{array}$ \\
\hline Change in zip code HPI in next 6 months & $\begin{array}{l}-0.1500 \\
(-9.74)^{* * *}\end{array}$ & $\begin{array}{l}-0.0784 \\
(-5.33)^{* * *}\end{array}$ & $\begin{array}{l}-0.1070 \\
(-3.08)^{* *}\end{array}$ & $\begin{array}{l}-0.1660 \\
(-2.71)^{* *}\end{array}$ & $\begin{array}{l}0.0458 \\
(1.65)\end{array}$ & $\begin{array}{l}0.0303 \\
(1.27)\end{array}$ & $\begin{array}{l}0.0951 \\
(0.89)\end{array}$ & $\begin{array}{l}0.1060 \\
(0.85)\end{array}$ & $\begin{array}{l}-0.1260 \\
(-8.04)^{* * *}\end{array}$ & $\begin{array}{l}-0.0143 \\
(-1.06)\end{array}$ & $\begin{array}{l}-0.0665 \\
(-2.88)^{* *}\end{array}$ & $\begin{array}{l}-0.1920 \\
(-4.32)^{* * *}\end{array}$ \\
\hline Unused \% of credit card limit (lag) & $\begin{array}{l}0.0526 \\
(43.24)^{* * *}\end{array}$ & $\begin{array}{l}0.0094 \\
(9.51)^{* * *}\end{array}$ & $\begin{array}{l}0.0615 \\
(19.50)^{* * *}\end{array}$ & $\begin{array}{l}0.1990 \\
(34.50)^{* * *}\end{array}$ & $\begin{array}{l}0.0289 \\
(12.98)^{* * *}\end{array}$ & $\begin{array}{l}0.0104 \\
(5.46)^{* * *}\end{array}$ & $\begin{array}{l}0.0609 \\
(7.14)^{* * *}\end{array}$ & $\begin{array}{l}0.0932 \\
(8.51)^{* * *}\end{array}$ & $\begin{array}{l}0.0298 \\
(24.44)^{* * *}\end{array}$ & $\begin{array}{l}0.0004 \\
(0.37)\end{array}$ & $\begin{array}{l}0.0185 \\
(10.61)^{* * *}\end{array}$ & $\begin{array}{l}0.0950 \\
(21.06)^{* * *}\end{array}$ \\
\hline Unused \% of HELOC limit (lag) & $\begin{array}{l}0.0066 \\
(8.02)^{* * *}\end{array}$ & $\begin{array}{l}-0.0008 \\
(-1.45)\end{array}$ & $\begin{array}{l}-0.0111 \\
(-2.66)^{* *}\end{array}$ & $\begin{array}{l}0.0060 \\
(0.73)\end{array}$ & $\begin{array}{l}-0.0001 \\
(-0.06)\end{array}$ & $\begin{array}{l}-0.0013 \\
(-1.41)\end{array}$ & $\begin{array}{l}0.0000 \\
(-0.00)\end{array}$ & $\begin{array}{l}-0.0069 \\
(-0.61)\end{array}$ & $\begin{array}{l}0.0031 \\
(2.62)^{* *}\end{array}$ & $\begin{array}{l}0.0000 \\
(-0.05)\end{array}$ & $\begin{array}{l}-0.0027 \\
(-0.83)\end{array}$ & $\begin{array}{l}-0.0042 \\
(-0.45)\end{array}$ \\
\hline Non-recourse primary mortgage & $\begin{array}{l}0.0068 \\
(5.55)^{* * *}\end{array}$ & $\begin{array}{l}0.0023 \\
(2.57)^{*}\end{array}$ & $\begin{array}{l}-0.0065 \\
(-1.75)\end{array}$ & $\begin{array}{l}0.0261 \\
(4.84)^{* * *}\end{array}$ & $\begin{array}{l}0.0083 \\
(4.44)^{* * *}\end{array}$ & $\begin{array}{l}0.0011 \\
(0.76)\end{array}$ & $\begin{array}{l}0.0096 \\
(1.36)\end{array}$ & $\begin{array}{l}0.0321 \\
(3.37)^{* * *}\end{array}$ & $\begin{array}{l}0.0074 \\
(5.23)^{* * *}\end{array}$ & $\begin{array}{l}-0.0023 \\
(-2.14)^{*}\end{array}$ & $\begin{array}{l}0.0014 \\
(0.51)\end{array}$ & $\begin{array}{l}0.0261 \\
(5.12)^{* * *}\end{array}$ \\
\hline Expected months from default to eviction in county & & & & & & & & & & & & \\
\hline 3-6 & $\begin{array}{l}-0.0004 \\
(-0.30)\end{array}$ & $\begin{array}{l}-0.0018 \\
(-1.30)\end{array}$ & $\begin{array}{l}-0.0049 \\
(-1.18)\end{array}$ & $\begin{array}{l}0.0500 \\
(2.91)^{* *}\end{array}$ & $\begin{array}{l}-0.0044 \\
(-1.63)\end{array}$ & $\begin{array}{l}-0.0033 \\
(-1.45)\end{array}$ & $\begin{array}{l}-0.0063 \\
(-0.42)\end{array}$ & $\begin{array}{l}0.0274 \\
(0.64)\end{array}$ & $\begin{array}{l}0.0012 \\
(0.91)\end{array}$ & $\begin{array}{l}0.0033 \\
(2.08)^{*}\end{array}$ & $\begin{array}{l}0.0000 \\
(-0.00)\end{array}$ & $\begin{array}{l}-0.0167 \\
(-1.99)^{*}\end{array}$ \\
\hline 6-9 & $\begin{array}{l}0.0033 \\
(1.59)\end{array}$ & $\begin{array}{l}0.0024 \\
(1.32)\end{array}$ & $\begin{array}{l}-0.0057 \\
(-0.87)\end{array}$ & $\begin{array}{l}0.0610 \\
(3.10)^{* *}\end{array}$ & $\begin{array}{l}-0.0088 \\
(-2.44)^{*}\end{array}$ & $\begin{array}{l}-0.0005 \\
(-0.17)\end{array}$ & $\begin{array}{l}-0.0369 \\
(-1.84)\end{array}$ & $\begin{array}{l}0.0068 \\
(0.14)\end{array}$ & $\begin{array}{l}0.0010 \\
(0.49)\end{array}$ & $\begin{array}{l}0.0018 \\
(0.91)\end{array}$ & $\begin{array}{l}-0.0004 \\
(-0.11)\end{array}$ & $\begin{array}{l}-0.0079 \\
(-0.73)\end{array}$ \\
\hline $9+$ & $\begin{array}{l}0.0065 \\
(2.83)^{* *}\end{array}$ & $\begin{array}{l}0.0013 \\
(0.61)\end{array}$ & $\begin{array}{l}0.0130 \\
(1.70)\end{array}$ & $\begin{array}{l}0.0742 \\
(3.17)^{* *}\end{array}$ & $\begin{array}{l}-0.0082 \\
(-1.99)^{*}\end{array}$ & $\begin{array}{l}-0.0025 \\
(-0.74)\end{array}$ & $\begin{array}{l}-0.0651 \\
(-2.41)^{*}\end{array}$ & $\begin{array}{l}0.1100 \\
(1.55)\end{array}$ & $\begin{array}{l}0.0006 \\
(0.24)\end{array}$ & $\begin{array}{l}0.0000 \\
(0.01)\end{array}$ & $\begin{array}{l}0.0038 \\
(0.87)\end{array}$ & $\begin{array}{l}-0.0134 \\
(-1.01)\end{array}$ \\
\hline Number of observations & 396924 & 269659 & 85866 & 41399 & 69883 & 53721 & 9348 & 6814 & 305342 & 122944 & 124338 & 58060 \\
\hline Adjusted R-squared & 0.255 & 0.158 & 0.245 & 0.430 & 0.287 & 0.215 & 0.316 & 0.401 & 0.136 & 0.061 & 0.122 & 0.192 \\
\hline
\end{tabular}


Table 3. Credit Card and Auto Loan Default

\begin{tabular}{|c|c|c|c|c|c|c|c|c|}
\hline \multirow{2}{*}{$\begin{array}{l}\text { Dependent variable: } \\
\text { Sample: }\end{array}$} & \multicolumn{4}{|c|}{ Credit Card Default } & \multicolumn{4}{|c|}{ Auto Loan Default } \\
\hline & $\overline{\text { All }}$ & LTV: $<90$ & LTV: $90-110$ & LTV: $>110$ & All & LTV: $<90$ & LTV: $90-110$ & LTV: $>110$ \\
\hline \multicolumn{9}{|l|}{ Combined LTV (lag): } \\
\hline $80-90$ & $\begin{array}{l}-0.0133 \\
(-10.55)^{* * *}\end{array}$ & $\begin{array}{l}-0.0157 \\
(-12.19)^{* * *}\end{array}$ & & & $\begin{array}{l}-0.0019 \\
(-1.69)\end{array}$ & $\begin{array}{l}-0.0022 \\
(-1.85)\end{array}$ & & \\
\hline $90-100$ & $\begin{array}{l}-0.0306 \\
(-21.95)^{* * *}\end{array}$ & & $\begin{array}{l}0.0068 \\
(3.06)^{* *}\end{array}$ & & $\begin{array}{l}-0.0044 \\
(-3.53)^{* * *}\end{array}$ & & $\begin{array}{l}0.0007 \\
(0.32)\end{array}$ & \\
\hline $100-110$ & $\begin{array}{l}-0.0303 \\
(-16.30)^{* * *}\end{array}$ & & & & $\begin{array}{l}-0.0050 \\
(-2.92)^{* *}\end{array}$ & & & \\
\hline $110-120$ & $\begin{array}{l}-0.0273 \\
(-10.70)^{* * *}\end{array}$ & & & $\begin{array}{l}0.0136 \\
(4.09)^{* * *}\end{array}$ & $\begin{array}{l}-0.0089 \\
(-3.72)^{* * *}\end{array}$ & & & $\begin{array}{l}-0.0012 \\
(-0.36)\end{array}$ \\
\hline $120+$ & $\begin{array}{l}-0.0372 \\
(-16.80)^{* * *}\end{array}$ & & & & $\begin{array}{l}-0.0081 \\
(-3.67)^{* * *}\end{array}$ & & & \\
\hline In(Primary mortgage balance) (lag) & $\begin{array}{l}-0.0129 \\
(-15.87)^{* * *}\end{array}$ & $\begin{array}{l}-0.0162 \\
(-17.78)^{* * *}\end{array}$ & $\begin{array}{l}-0.0024 \\
(-1.00)\end{array}$ & $\begin{array}{l}-0.0093 \\
(-2.63)^{* *}\end{array}$ & $\begin{array}{l}-0.0079 \\
(-10.19)^{* * *}\end{array}$ & $\begin{array}{l}-0.0070 \\
(-7.90)^{* * *}\end{array}$ & $\begin{array}{l}-0.0138 \\
(-6.24)^{* * *}\end{array}$ & $\begin{array}{l}-0.0031 \\
(-0.91)\end{array}$ \\
\hline Minimum credit card payment/primary mortgage payment (lag) & $\begin{array}{l}0.0080 \\
(6.04)^{* * *}\end{array}$ & $\begin{array}{l}-0.0097 \\
(-5.60)^{* * *}\end{array}$ & $\begin{array}{l}0.0299 \\
(10.34)^{* * *}\end{array}$ & $\begin{array}{l}0.0337 \\
(7.77)^{* * *}\end{array}$ & & & & \\
\hline Account balance / primary mortgage balance (lag) & & & & & $\begin{array}{l}-0.0004 \\
(-2.06)^{*}\end{array}$ & $\begin{array}{l}-0.0007 \\
(-1.38)\end{array}$ & $\begin{array}{l}-0.0001 \\
(-0.70)\end{array}$ & $\begin{array}{l}0.0112 \\
(0.51)\end{array}$ \\
\hline Change in zip code HPI in next 6 months & $\begin{array}{l}0.0175 \\
(0.92)\end{array}$ & $\begin{array}{l}0.0431 \\
(1.81)\end{array}$ & $\begin{array}{l}-0.0370 \\
(-0.93)\end{array}$ & $\begin{array}{l}0.0078 \\
(0.14)\end{array}$ & $\begin{array}{l}0.0122 \\
(0.67)\end{array}$ & $\begin{array}{l}0.0277 \\
(1.15)\end{array}$ & $\begin{array}{l}0.0077 \\
(0.20)\end{array}$ & $\begin{array}{l}-0.0057 \\
(-0.10)\end{array}$ \\
\hline Unused \% of credit card limit (lag) & $\begin{array}{l}-0.1180 \\
(-67.73)^{* * *}\end{array}$ & $\begin{array}{l}-0.1280 \\
(-57.49)^{* * *}\end{array}$ & $\begin{array}{l}-0.0873 \\
(-23.34)^{* * *}\end{array}$ & $\begin{array}{l}-0.1100 \\
(-22.00)^{* * *}\end{array}$ & $\begin{array}{l}0.0011 \\
(0.74)\end{array}$ & $\begin{array}{l}0.0006 \\
(0.31)\end{array}$ & $\begin{array}{l}0.0035 \\
(1.09)\end{array}$ & $\begin{array}{l}0.0044 \\
(0.93)\end{array}$ \\
\hline Unused \% of HELOC limit (lag) & $\begin{array}{l}-0.0005 \\
(-0.52)\end{array}$ & $\begin{array}{l}0.0030 \\
(3.05)^{* *}\end{array}$ & $\begin{array}{l}0.0017 \\
(0.45)\end{array}$ & $\begin{array}{l}0.0028 \\
(0.57)\end{array}$ & $\begin{array}{l}-0.0018 \\
(-1.96)^{*}\end{array}$ & $\begin{array}{l}-0.0010 \\
(-0.99)\end{array}$ & $\begin{array}{l}-0.0053 \\
(-1.79)\end{array}$ & $\begin{array}{l}-0.0060 \\
(-1.05)\end{array}$ \\
\hline Non-recourse primary mortgage & $\begin{array}{l}-0.0033 \\
(-2.37)^{*}\end{array}$ & $\begin{array}{l}0.0014 \\
(0.90)\end{array}$ & $\begin{array}{l}-0.0003 \\
(-0.08)\end{array}$ & $\begin{array}{l}-0.0240 \\
(-5.48)^{* * *}\end{array}$ & $\begin{array}{l}0.0004 \\
(0.29)\end{array}$ & $\begin{array}{l}0.0012 \\
(0.79)\end{array}$ & $\begin{array}{l}-0.0046 \\
(-1.18)\end{array}$ & $\begin{array}{l}-0.0058 \\
(-1.23)\end{array}$ \\
\hline \multicolumn{9}{|l|}{ Expected months from default to eviction in county: } \\
\hline $3-6$ & $\begin{array}{l}0.0044 \\
(1.60)\end{array}$ & $\begin{array}{l}0.0053 \\
(1.69)\end{array}$ & $\begin{array}{l}-0.0060 \\
(-0.95)\end{array}$ & $\begin{array}{l}0.0303 \\
(1.93)\end{array}$ & $\begin{array}{l}0.0006 \\
(0.28)\end{array}$ & $\begin{array}{l}-0.0012 \\
(-0.47)\end{array}$ & $\begin{array}{l}0.0037 \\
(0.72)\end{array}$ & $\begin{array}{l}0.0187 \\
(1.63)\end{array}$ \\
\hline 6-9 & $\begin{array}{l}0.0031 \\
(0.91)\end{array}$ & $\begin{array}{l}0.0067 \\
(1.73)\end{array}$ & $\begin{array}{l}-0.0088 \\
(-1.04)\end{array}$ & $\begin{array}{l}0.0380 \\
(2.06)^{*}\end{array}$ & $\begin{array}{l}-0.0011 \\
(-0.39)\end{array}$ & $\begin{array}{l}-0.0017 \\
(-0.49)\end{array}$ & $\begin{array}{l}-0.0036 \\
(-0.53)\end{array}$ & $\begin{array}{l}0.0187 \\
(1.19)\end{array}$ \\
\hline $9+$ & $\begin{array}{l}0.0042 \\
(1.14)\end{array}$ & $\begin{array}{l}0.0034 \\
(0.82)\end{array}$ & $\begin{array}{l}-0.0079 \\
(-0.82)\end{array}$ & $\begin{array}{l}0.0770 \\
(3.39)^{* * *}\end{array}$ & $\begin{array}{l}0.0067 \\
(2.01)^{*}\end{array}$ & $\begin{array}{l}0.0058 \\
(1.52)\end{array}$ & $\begin{array}{l}0.0044 \\
(0.53)\end{array}$ & $\begin{array}{l}0.0398 \\
(1.94)\end{array}$ \\
\hline Number of observations & 396924 & 269659 & 85866 & 41399 & 186280 & 119356 & 46076 & 20848 \\
\hline Adjusted R-squared & 0.355 & 0.360 & 0.338 & 0.391 & 0.093 & 0.099 & 0.078 & 0.079 \\
\hline
\end{tabular}

